\title{
Uji Efektifvitas Cendawan Mikoriza Lokal Gerogak Lahan Kering dan Komersial Pada Tanaman Jagung (Zea mays 1.)
}

\author{
Julianus Jeksen \\ Julianus_jeksen@yahoo.com \\ Program Studi Agroekoteknologi, Fakultas Pertanian \\ Universitas Flores, Ende
}

\begin{abstract}
Dry land in Indonesia has been dominated by acid soils, so that availability of phosphate $(\mathrm{P})$ becomes the main obstacle in improving outcomes and only 10-30\% of fertilizer P can be utilized by plants. One of solution to meet the needs of phosphate is by utilization of mycorrhizal biofertilizer. These experiment were divided into several phases: 1) Looking for phases of mycorrhizal, 2) the laboratory analysis, 3) Testing phase on plants that were carried out by using polybags with sterile soil.

The experiment was designed with a complete randomized block design (RAKL) by using a factor that consist of 6 treatments that are: 1) Without mycorrhizal inoculum $\left(\mathrm{M}_{0}\right)$, 2) Mycorrhizal inoculum $5 \mathrm{~g}+50$ Spores $\left(\mathrm{M}_{5}\right)$, 3) Mycorrhizal inoculum $10 \mathrm{~g}+50$ spores $\left.\left(\mathrm{M}_{10}\right), 4\right)$ Mycorrhizal inoculum $15 \mathrm{~g}+50$ spore $\left.\left(\mathrm{M}_{15}\right), 5\right)$ Mycorrhizal inoculum $20 \mathrm{~g}+50$ spore $\left.\left(\mathrm{M}_{20}\right), 6\right)$ Commercial mycorrhizal $10 \mathrm{~g}(\mathrm{Mk})$. All treatments was repeated four times so that total 24 pot experiment.

The experiment results show that mycorrhizal treatment given on the corn crop has very significant $(\mathrm{P}<0.01)$ to the number of leaf age of 35, 49, 63 days after, leaf wide have age 49 day after plant, fresh weight, oven dry weight, absorb $\mathrm{P}$, number of spores, mycorrhizal infection and significant effect $(P<0.05)$ to plant height age of 35, 49, 63 day after plant, 63 day afer plant, leaf wide, and P-available. Based on the results of this study will be suggested, in order to enhance the growth of corn plants can be used locally mikroiza a dose of $10 \mathrm{~g}+50$ spores.
\end{abstract}

Key words: Mycorrhizal, Corn

\section{PENDAHULUAN}

Lahan kering berpotensi untuk dikembangkan menjadi lahan pertanian produktif mengingat sebarannya yang sangat luas di Indonesia. Lahan kering di Bali, khususnya di Kecamatan Gerogak sebagian didominasi oleh tanah agak masam sehingga ketersediaan fosfat $(\mathrm{P})$

menjadi kendala utama dalam
meningkatkan hasil serta hanya 10-30\% dari pemupukan $\mathrm{P}$ dapat dimanfaatkan oleh tanaman (Anonim, $t \mathrm{t}$ ). Hal ini terjadi karena adanya proses pengikatan atau fiksasi P yang cukup tinggi oleh koloid tanah terhadap pupuk yang diberikan. Tanah yang bersifat masam ( $\mathrm{pH}$ rendah), fiksasi $\mathrm{P}$ dilakukan oleh besi $(\mathrm{Fe})$ atau 
Julianus: Uji efektivitas cendawan mikoriza lokal gerogak lahan kering dan komersial pada tanaman jagung (Zea mays L.)

aluminium (Al) dan terbentuk ikatan Fe-P atau Al-P yang juga sukar larut dan tidak tersedia bagi tanaman (Prihastuti, dkk, 2008). Defisiensi fosfat sangat tersebar luas di Indonesia (Sarief, 1985).

Salah satu solusi untuk memenuhi kebutuhan fosfat adalah dengan pemanfaatan pupuk hayati. Pupuk hayati merupakan mikroorganisme hidup yang diberikan ke dalam tanah sebagai inokulan untuk membantu tanaman memfasilitasi atau menyediakan unsur hara tertentu bagi tanaman. Salah satu jenis mikroorganisme penting dalam memanfaatkan fosfat yang ada di dalam tanah adalah cendawan mikoriza yang berpotensi menyediakan berbagai unsur hara bagi tanaman terutama fosfat. Menurut Imas dkk (1989) beberapa manfaat yang dapat diperoleh oleh tanaman inang dari adanya asosiasi mikoriza adalah dapat meningkatkan penyerapan unsur hara, meningkatkan ketahanan terhadap kekeringan, tahan terhadap patogen akar serta memproduksi hormon dan zat pengatur tumbuh.

Selama ini mikoriza yang beredar di pasaran adalah mikoriza komersial yang merupakan hasil isolasi dari suatu daerah sehingga ketika diaplikasi pada daerah lain kemampuan dari mikoriza ini belum tentu efektif jika dibandingkan dengan mikoriza lokal mengingat lingkungannya yang berbeda. Pengembangan mikoriza yang bersifat lokal diharapkan mampu berkembang dan memberikan hasil yang maksimum karena mikoriza ini telah mampu beradaptasi terhadap lingkungan setempat baik biotik maupun abiotik. Hasil penelitian Musfal (2008) mendapatkan bahwa efektivitas cendawan mikoriza ditentukan oleh faktor abiotik seperti $\mathrm{pH}$, kadar air, konsentrasi hara, suhu, pengolahan tanah, pemberian pupuk dan pestisida. Faktor biotik seperti interaksi cendawan mikoriza dengan tanaman inangnya, tipe perakaran tanaman inangnya, dan kompetisi antar cendawan itu sendiri. Menurut Hapsoh (2008) faktor yang mempengaruhi perkembangan cendawan mikoriza adalah tanaman inang, suhu, kelembaban, pH, cahaya, ketersediaan hara dan pestisida. Cendawan mikoriza merupakan satu kelompok jamur tanah biotrof obligat yang tidak dapat melestarikan pertumbuhan dan reproduksinya bila terpisah dari tanaman inang (Simanungkalit, 2006). Salah satu teknik yang dapat digunakan untuk 
Julianus: Uji efektivitas cendawan mikoriza lokal gerogak lahan kering dan komersial pada tanaman jagung (Zea mays L.)

memperoleh inokulan mikoriza melalui perbanyakan pada tanaman jagung. Tanaman jagung dipilih sebagai tanaman inang untuk perbanyakan mikoriza karena jagung mempunyai sistem perakaran yang banyak, pertumbuhan relatif lebih pendek, dan daya adaptasi tinggi terutama di lahan-lahan kering. Hal ini didukung oleh hasil penelitian Abdullah, dkk. (2005) yang melaporkan bahwa jagung merupakan tanaman yang baik untuk mengembangbiakan inokulan cendawan mikoriza.

Tujuan penelitian ini untuk mengetahui apakah tanaman pertanian yang ada di Gerogak terinfeksi oleh mikoriza dan mengetahui keefektifan cendawan mikoriza lokal Gerogak terhadap pertumbuhan tanaman jagung.

\section{BAHAN DAN METODE}

Pelaksanaan percobaan ini terbagi menjadi tiga tahap yaitu : 1) Tahap penjaringan mikoriza dilaksanakan di Desa Pejarakan, Kecamatan Gerogak, Kabupaten Buleleng. Pelaksanaan penjaringan dimulai dari bulan Desember 2010 sampai dengan bulan Januari 2011, 2) Tahap analisis laboratorium dilaksanakan di Laboratorium Mikrobiologi, Fakultas Matematika dan
Ilmu Pengetahuan Alam, Universitas Udayana, Bukit Jimbaran. Pelaksanaan analisis laboratorium dimulai dari bulan Februari 2011 sampai dengan bulan Juni 2011, 3) Tahap pengujian pada tanaman jagung dilaksanakan di kebun bibit, Balai Pembibitan Tanaman Hutan Provinsi Bali. Pelaksanan pengujian dimulai dari bulan Juli 2011 sampai dengan bulan September 2011.

Bahan yang digunakan dalam percobaan ini adalah sampel tanah dari Gerogak, mikoriza komersial, larutan 10 $\% \mathrm{KOH}$, larutan $\mathrm{HCl}$, asam laktat, larutan pewarna, larutan pencuci warna, larutan $\mathrm{H}_{2} \mathrm{O}_{2}$, alkohol, dan benih jagung sedangkan alat yang digunakan dalam percobaan ini adalah saringan berbagai ukuran, sentrifius dengan rotor horizontal, cawan petri yang berkotakkotak, mikroskop stereo dan mikroskop binokuler, dan autoklaf.

Rancangan yang digunakan dalam percobaan ini adalah Rancangan Acak Kelompok Lengkap (RAKL) yang terdiri dari 6 perlakuan yaitu: $\mathrm{M}_{0}$ : Tanpa inokulum mikoriza, $\mathrm{M}_{5}$ : Inokulum mikoriza $5 \mathrm{~g}+50$ spora, $\mathrm{M}_{10}$ : Inokulum mikoriza10 g + 50 spora, $\mathrm{M}_{15}$ :Inokulum mikoriza $15 \mathrm{~g}+50$ spora, $\mathrm{M}_{20}$ : Inokulum 
Julianus: Uji efektivitas cendawan mikoriza lokal gerogak lahan kering dan komersial pada tanaman jagung (Zea mays L.)

mikoriza $20 \mathrm{~g}+50$ spora Mk: Mikoriza komersial $10 \mathrm{~g}$

Semua perlakuan diulang sebanyak empat kali sehingga terdapat 24 pot percobaan.

Variabel yang diamati meliputi variable pertumbuhan dan beberapa sifat kimia tanah Serapan $\mathrm{P}$ tanaman, $\mathrm{P}$ tersedia tanah (metode Bray $^{-1}$ ), C-organik tanah(metode Walkey \& Black), Jumlah Spora, Infeksi mikoriza. Data hasil pengamatan dianalisis dengan menggunakan analisis sidik ragam sesuai dengan rancangan yang digunakan. Apabila perlakuan menunjukkan pengaruh yang nyata atau sangat nyata terhadap variabel yang diamati, maka pengujian dilanjutkan dengan uji nilai beda rata-rata menggunakan uji jarak berganda Duncan 5\% (Gomez dan Gomez, 1995).

\section{HASIL DAN PEMBAHASAN}

Berdasarkan pengamatan infeksi mikoriza pada tanaman-tanaman yang ada di Gerogak, ditemukan bahwa mikoriza menginfeksi lebih banyak pada tanaman jagung dan kacang tanah kemudian diikuti oleh tanaman ubi kayu, cabai serta kacang undis dan paling sedikit menginfeksi tanaman terong dan jambu mete. Pada tanaman lamtoro, jati, trembesi dan turi tidak ditemukan adanya infeksi mikoriza hal ini kemungkinan bisa disebabkan oleh kondisi kesuburan tanah pada tanaman-tanaman di atas dalam keadaan tidak kekurangan unsur hara. Hal di atas sesuai dengan teori "Dasar fisik Mikotrofi" dalam teori ini dikemukakan bahwa mikoriza akan dibentuk jika terdapat suatu ketidakseimbangan di dalam ketersediaan satu atau lebih dari empat unsur hara makro yakni nitrogen $(\mathrm{N})$, fosfat $(\mathrm{P})$, kalium (K) dan kalsium (Ca) (Hatch, 1973, dalam Setiadi, 1989).

Hasil analisis statistika menunjukkan bahwa perlakuan mikoriza yang diberikan pada tanaman jagung berpengaruh sangat nyata $(\mathrm{P}<0,01)$ terhadap jumlah daun umur 35, 49, 63 hst, luas daun umur 49 hst, berat berangkasan segar, berat berangkasan kering oven, serapan-P, jumlah spora, infeksi mikoriza dan berpengaruh nyata $(\mathrm{P}<0,05)$ terhadap tinggi tanaman umur 35, 49, 63 hst, luas daun umur 63 hst, dan P-tersedia.

Hasil analisis statistika menunjukkan bahwa pengaruh mikoriza baik mikoriza komersial maupun mikoriza lokal 
Julianus: Uji efektivitas cendawan mikoriza lokal gerogak lahan kering dan komersial pada tanaman jagung (Zea mays L.)

berpengaruh sangat nyata terhadap berat berangkasan segar dan kering oven jika dibandingkan dengan tanpa inokulum mikoriza $\left(\mathrm{M}_{0}\right)$. Tetapi jika dibandingkan antara mikoriza komersial dengan mikoriza lokal pada berbagai dosis perlakuan keduanya memiliki nilai yang tidak berbeda nyata. Berat berangkasan segar tertinggi yaitu 187,90 g $\tan ^{-1}$ diperoleh pada perlakuan inokulum mikoriza $10 \mathrm{~g}+50$ spora $\left(\mathrm{M}_{10}\right)$ atau lebih tinggi sebesar $34,73 \%$ dari berat berangkasan segar pada perlakuan tanpa inokulum mikoriza $\left(\mathrm{M}_{0}\right)$ dan berat berangkasan kering oven tertinggi yaitu 47,59 $\mathrm{g} \mathrm{tan}^{-1}$ diperoleh pada perlakuan inokulum mikoriza $10 \mathrm{~g}+50$ spora $\left(\mathrm{M}_{10}\right)$ atau lebih tinggi sebesar 42,10\% dari berat berangkasan kering oven pada perlakuan tanpa inokulum mikoriza $\left(\mathrm{M}_{0}\right)$. Berdasarkan hasil di atas terlihat bahwa dengan inokulum mikoriza lokal sebanyak $10 \mathrm{~g}+50$ spora dapat memberikan hasil berat segar dan kering oven berangkasan yang tidak jauh berbeda dengan dosis mikoriza komersial pada dosis $10 \mathrm{~g}$. Berat berangkasan segar dan kering oven yang tinggi disebabkan oleh pertumbuhan tanaman yang lebih baik seperti tinggi tanaman, jumlah daun, dan luas daun. Perlakuan mikoriza memberikan pengaruh yang nyata terhadap tinggi tanaman umur 35, 49, dan 63 hst. Tingginya nilai variabel pertumbuhan yang diperoleh ini dipengaruhi oleh adanya infeksi mikoriza pada akar tanaman. Mikoriza selain membantu penyerapan $\mathrm{P}$ juga dapat meningkatkan penyerapan $\mathrm{N}$ dan $\mathrm{K}$ yang bersifat mobil. Menurut Hapsoh (2008) mikoriza mengandung nitrat reduktase sehingga hifa eksternalnya mempunyai kapasitas menyerap nitrat. Data diatas memperlihatkan bahwa pemberian mikoriza mampu meningkatkan penyerapan hara dan memberikan pertumbuhan tanaman yang lebih baik. Hal yang sama juga dilaporkan oleh Kabirun (2002) bahwa dengan pemberian mikoriza pada padi gogo di tanah entisol mampu meningkatkan pertumbuhan tanaman serta berat kering tanaman.

Perlakuan mikoriza memberikan pengaruh sangat nyata terhadap jumlah spora. Jumlah spora tertinggi yaitu 47 spora diperoleh pada perlakuan inokulum mikoriza $15 \mathrm{~g}+50$ spora $\left(\mathrm{M}_{15}\right)$ atau lebih tinggi sebesar $81,91 \%$ dari jumlah spora pada perlakuan tanpa inokulum mikoriza $\left(\mathrm{M}_{0}\right)$. Jumlah spora mikoriza komersial 
Julianus: Uji efektivitas cendawan mikoriza lokal gerogak lahan kering dan komersial pada tanaman jagung (Zea mays L.)

tidak berbeda nyata jika dibandingkan dengan mikoriza lokal pada berbagai perlakuan dosis kecuali pada perlakuan inokulum mikoriza $5 \mathrm{~g}+50$ spora $\left(\mathrm{M}_{5}\right)$. Penelitian ini mengggunakan tanah steril tetapi kenyataannya masih ditemukan spora mikoriza pada perlakuan tanpa inokulum mikoriza $\left(\mathrm{M}_{0}\right)$ dan hal ini kemungkinan disebabkan oleh penggunaan pupuk kascing pada saat percobaan ataupun karena akar tanaman keluar menembus polibag. Banyak faktor yang dapat mempengaruhi perkembangan spora mikoriza seperti spesies dengan tanaman inang, suhu, kelembaban, $\mathrm{pH}$ tanah, cahaya dan ketersediaan hara (Handayanto, 2007).

Persentase infeksi mikoriza pada akar tanaman ditentukan oleh aktif atau tidaknya spora daripada mikoriza itu sendiri. Nilai persentase infeksi mikoriza baik itu mikoriza komersial maupun mikoriza lokal sangat berbeda nyata jika dibandingkan dengan tanpa inokulum mikoriza $\left(\mathrm{M}_{0}\right)$. Persentase infeksi mikoriza tertinggi yaitu $28,81 \%$ pada perlakuan inokulum mikoriza $10 \mathrm{~g}+50$ spora $\left(\mathrm{M}_{10}\right)$ atau lebih tinggi $85,94 \%$ dari perlakuan tanpa inokulum mikoriza $\left(\mathrm{M}_{0}\right)$. Persentase infeksi mikoriza komersial tidak berbeda nyata jika dibandingkan dengan mikoriza lokal pada berbagai perlakuan dosis kecuali pada perlakuan mikoriza lokal dengan perlakuan inokulum mikoriza $5 \mathrm{~g}+50$ spora $\left(\mathrm{M}_{5}\right)$, dengan demikian berarti secara umum bahwa mikoriza lokal gerogak pada berbagai dosis perlakuan mempunyai kemampuan yang sama jika dibandingkan dengan mikoriza komersial dengan dosis $10 \mathrm{~g}$. Walaupun ditemukan spora pada perlakuan tanpa inokulum mikoriza $\left(\mathrm{M}_{0}\right)$ tetapi tidak sampai mengifeksi tanaman, karena spora kemungkinan dalam keadaan kurang aktif. Infeksi mikoriza akan berpengaruh positif terhadap variabel pertumbuhan tanaman jagung (Gerderman, 1964 dalam Simanungkalit, 2006). Tanaman yang bermikoriza biasanya tumbuh lebih baik dari pada yang tidak bermikoriza, karena mikoriza secara efektif dapat meningkatkan penyerapan unsur hara makro dan beberapa unsur hara mikro. Selain itu akar yang bermikoriza dapat menyerap unsur hara dalam bentuk terikat dan tidak tersedia untuk tanaman (Serrrano, 1985 dalam Imas dkk, 1989).

Infeksi mikoriza pada akar tanaman jagung merupakan indikasi adanya 
Julianus: Uji efektivitas cendawan mikoriza lokal gerogak lahan kering dan komersial pada tanaman jagung (Zea mays L.)

simbiosis antara mikoriza dengan akar tanaman jagung. Santoso

mengatakan bahwa mikoriza merupakan organisme yang hidup secara simbiosis mutualistis dengan tanaman inangnya. Menurut Handayanto (2007) hifa jamur mikoriza sangat berpotensi untuk meningkatkan luas permukaan serapan akar sampai dengan $80 \%$, sehingga cendawan mikoriza dapat meningkatkan penyerapan berbagai unsur hara sehingga status nutrisi tanaman dapat diperbaiki, terbukti dengan meningkatnya serapan $\mathrm{P}$ tanaman. Serapan $\mathrm{P}$ tanaman tertinggi yaitu $0,23 \mathrm{~g} \mathrm{tan}^{-1}$ tercapai pada perlakuan inokulum mikoriza $10 \mathrm{~g}+50$ spora $\left(\mathrm{M}_{10}\right)$ atau lebih tinggi sebesar 52,17\% dari serapan $\mathrm{P}$ tanaman pada perlakuan tanpa inokulum mikoriza $\left(\mathrm{M}_{0}\right)$, tetapi jika dibandingkan antara mikoriza komersial dengan mikoriza lokal pada berbagai perlakuan dosis keduanya memiliki nilai yang tidak berbeda nyata. Semakin tinggi serapan $\mathrm{P}$ menyebabkan proses metabolisme semakin baik sehingga pada akhirnya dapat meningkatkan pertumbuhan tanaman. Meningkatnya serapan $\mathrm{P}$ akibat pemberian mikoriza erat kaitannya dengan peran dan fungsi dari cendawan mikoriza. Menurut Baon
(1997) mikoriza dapat memperbesar penyerapan $\mathrm{P}$ dan unsur-unsur hara lainnya walaupun dalam jumlah yang lebih kecil seperti $\mathrm{N}$ dan $\mathrm{K}$ melalui perpanjangan mycelia yang berkembang sangat luas di luar struktur akar tanaman. Fosfat pada tanaman berfungsi untuk merangsang pertumbuhan akar, transfer energi, penyusunan protein sehingga menjamin lebih baiknya proses metabolisme dalam tanaman seperti proses transportasi dan alokasi fotosintat.

Meningkatnya ketersediaan P dalam tanah erat kaitannya dengan penambahan mikoriza sebagai mikroba tanah. Mikoriza mempunyai enzim fosfatase yang dapat membantu penyerapan $\mathrm{P}$ dari tidak tersedia menjadi tersedia bagi tanaman. Mekanismenya adalah asam fosfatase yang terdapat pada hifa yang sedang aktif tumbuh serta peningkatan aktivitas enzim fosfatase pada permukaan akar akibat infeksi mikoriza menyebabkan fosfat anorganik dibebaskan dari fosfat organik pada daerah dekat permukaan sel akar sehingga memudahkan fosfat dapat diserap (Kartini, 1997). P-tersedia tertinggi yaitu 159,41 ppm diperoleh pada perlakuan inokulum mikoriza $5 \mathrm{~g}+$ 
Julianus: Uji efektivitas cendawan mikoriza lokal gerogak lahan kering dan komersial pada tanaman jagung (Zea mays L.)

50 spora $\left(\mathrm{M}_{5}\right)$ atau lebih tinggi sebesar $16,50 \%$ dari P-tersedia pada perlakuan tanpa inokulum mikoriza $\left(\mathrm{M}_{0}\right)$, tetapi jika dibandingkan antara mikoriza komersial dan mikoriza lokal pada berbagai perlakuan dosis keduanya memiliki nilai yang tidak berbeda nyata.

Berdasarkan hasil di atas dapat dikatakan bahwa inokulum mikoriza lokal baik itu pada dosis $5 \mathrm{~g}, 10 \mathrm{~g}, 15 \mathrm{~g}$, $20 \mathrm{~g}+50$ spora dapat memberikan hasil yang tidak jauh berbeda dengan dosis mikoriza komersial pada dosis $10 \mathrm{~g}$. Cendawan mikoriza lokal Gerogak mempunyai efektifvitas yang tidak jauh berbeda dengan mikoriza komersial pada dosis 10 g karena mikoriza lokal ini sudah mampu beradaptasi terhadap lingkungannya baik itu biotik maupun abiotik. Hal di atas didukung oleh hasil penelitian Musfal (2008) yang menyatakan bahwa efektivitas cendawan mikoriza ditentukan oleh faktor abiotik seperti $\mathrm{pH}$, kadar air, konsentrasi hara, suhu, pengolahan tanah, pemberian pupuk dan pestisida. Faktor biotik seperti interaksi cendawan mikoriza dengan tanaman inangnya, tipe perakaran tanaman inangnya, dan kompetisi antar cendawan itu sendiri. Perlakuan mikoriza lokal yang banyak memberikan hasil terbaik yaitu pada perlakuan mikoriza 10 $\mathrm{g}+50$ spora $\left(\mathrm{M}_{10}\right)$, hal ini ditunjukkan pada hasil berat berangkasan segar, berat kering oven, persentase infeksi, serapan $\mathrm{P}$ tinggi tanaman umur 49 dan 63 hst, jumlah daun umur 49 dan 63 hst, luas daun umur 49 dan 63 hst.

\section{Kesimpulan}

Berdasarkan hasil penelitian dapat disimpulkan bahwa tanaman pertanian yang ada di Gerogak terinfeksi oleh mikoriza dan cendawan mikoriza lokal Gerogak pada dosis $10 \mathrm{~g}+50$ spora mempunyai efektifitas yang lebih baik untuk pertumbuhan tanaman jagung jika dibandingkan dengan mikoriza komersial dengan dosis $10 \mathrm{~g}$.

\section{Ucapan Terima Kasih.}

Pada kesempatan ini penulis ingin mengucapkan terima kasih kepada semua pihak yang telah membantu dengan caranya masing-masing dalam melengkapi tulisan ini.

\section{DAFTAR PUSTAKA}

Abdullah, S. Musa, Y. Feranita, H. 2005. Perbanyakan Cendawan Mikoriza Arbuskular pada Berbagai Varietas Jagung. J. Sains \& Teknologi. 5(1) : $12-20$ 
Julianus: Uji efektivitas cendawan mikoriza lokal gerogak lahan kering dan komersial pada tanaman jagung (Zea mays L.)

Baon, J. B. 1997. Peranan Mikoriza dalam Melestarikan Sumberdaya Tanah Pertanian. dalam : Soedaryono, Taufik A., Winarto, A., editors. Perlindungan Sumberdaya untuk Mendukung Kelestarian Tanah. Edisi Khusus Balitkabi, Malang : hal. 314-323.

Gomez, K.A., Gomez, A.A. 1995. Prosedur Statistik untuk Penelitian Pertanian. (Syamsuddin, E., Baharsyah, J.S., Pentj). Jakarta:Universitas Indonesia. 698 hal.

Handayanto dan Hairiah, K. 2007. Biologi Tanah. Yogyakarta : Pustaka Adipura. 194 hal.

Hapsoh. 2008. Pemanfaatan Fungi Mikoriza Arbuskula pada Budidaya Kedelai di Lahan Kering. Pidato Pengukuhan Jabatan Guru Besar Tetap dalam Bidang Ilmu Budidaya Pertanian pada Fakultas Pertanian Universitas Sumatera Utara Medan. 19 hal.

Imas, T., Ratna, S.H., Agustin, W.G., Yadi, S. 1989. Mikrobiologi Tanah II. Bogor: Departemen Pendidikan dan Kebudayaan Direktorat Jenderal Pendidikan Tinggi. Pusat Antar Universitas Bioteknologi Institut Pertanian Bogor. 143 hal.

Kabirun, S. 2002. Tanggap Padi Gogo terhadap Inokulasi Mikoriza Arbuskula dan Pemupukan Fosfat pada Tanah Entisol. Fakultas Pertaanian, UGM. Yogyakarta. Jurnal Ilmu Tanah dan Lingkungan. Vol 3(2) hal 49-56
Musfal. 2008. "Efektivitas Cendawan Mikoriza Arbuskula (CMA) terhadap Pemberian Pupuk Spesifik Lokasi Tanaman Jagung pada Tanah Inceptisol". (tesis). Medan: Universitas Sumatra Utara.

Santoso, B. 1994. Mikoriza, Peranan dan Hubungannya dengan Kesuburan Tanah. Malang : Universitas Brawijaya Fakultas Pertanian. Jurusan Tanah. 40 hal.

Sarief, S. 1985. Kesuburan dan Pemupukan Tanah Pertanian. Bandung: CV Pustaka Buana. 182 hal.

Setiadi, Y. 1989. Pemanfaatan Mikro Organisme dalam Kehutanan. Bogor: Departemen Pendidikan dan Kebudayaan, Direktorat Jenderal Pendidikan Tinggi. Pusat Antar Universitas Bioteknologi Institut Pertanian Bogor. 102 hal.

Simanungkalit, R. D. M. 2006. Cendawan Mikoriza Arbuskuler. Dalam: Simanungkalit, R. D. M., Suriadikarta, D. A., Saraswati, R., Setyorini, D., Hartatik, W., Editor. Pupuk Organik dan Pupuk Hayati. Balai Besar Litbang Sumberdaya Lahan Pertanian. Bogor: Badan Penelitian dan Pengembangan Pertanian. hal. 159-190.

Zuhri, S. 2010. Produksi Jagung Tidak Cukup. (cited 2010 November 03 ${ }^{\text {th }}$ ) Available from: URL: http://bataviase.co.id/node/225455 